\title{
Predominância de Begomovírus em Tomateiros na Região Produtora da Ibiapaba, Ceará, e sua Detecção Natural em Plantas Daninhas
}

\author{
Luciana S.E.P. Arnaud ${ }^{1}$, Carmem D.G. Santos ${ }^{1}$, José A.A. Lima ${ }^{1} \&$ Francisco A. A. Feitosa ${ }^{2}$ \\ ${ }^{1}$ Departamento de Fitotecnia, Universidade Federal do Ceará, Cx. Postal 12.168, CEP 60356-001, Fortaleza, CE, Brasil, \\ e-mail:carmelo@ufc.br; ${ }^{2}$ Associação de Produtores da Chapada da Ibiapaba, CEP 60356-001, Guaraciaba do Norte, CE, Brasil
}

Autor para correspondência: Carmem D. G. Santos

ARNAUD, L.S.E.P., SANTOS, C.D.G., LIMA, J.A.A. \& FEITOSA, F.A.A. Predominância de begomovírus em tomateiros na região produtora da Ibiapaba, Ceará, e sua detecção natural em plantas daninhas. Fitopatologia Brasileira 32:241246. 2007.

\begin{abstract}
RESUMO
O tomateiro, Lycopersicon esculentum Mill., hortaliça de grande importância econômica para o Brasil, apresenta muitos problemas fitossanitários, dentre os quais as viroses. Os vírus associados à cultura no país pertencem aos gêneros Begomovirus, mais frequentemente relatado, Potyvirus, Cucumovirus, Tospovirus e Tobamovirus. No Ceará, apesar de relatos da incidência de viroses em tomateiros na Chapada da Ibiapaba, maior região produtora do estado, há escassez de informações sobre a situação atual da ocorrência de begomovírus, nas diversas lavouras daquele agropólo. Assim, foram objetivos deste trabalho: realizar levantamento da presença de begomovírus nas cultivares e híbridos de tomateiro explorados comercialmente na Ibiapaba; verificar a ocorrência de plantas daninhas infectadas e investigar a transmissão artificial de begomovírus isolados de tomateiro e de plantas daninhas para tomateiro. Os testes sorológicos e a PCR realizados detectaram begomovírus em 'Alambra', 'Densus', 'Monalisa', 'Santa Clara', 'Sheila', 'Sofia', 'Raisa-N' e 'TY- Fanny', cultivares e híbridos mais cultivados nas lavouras. Além de begomovírus, Cucumber mosaic virus (CMV) e Potato virus $Y$ (PVY) foram também detectados. As plantas daninhas Amaranthus spinosus, A. viridis, Ageratum conyzoides e Bidens pilosa foram identificadas como hospedeiras naturais de begomovírus. A transmissão de begomovírus de tomateiro para tomateiro ocorreu em inoculações por enxertia e via extrato foliar e de plantas daninhas infectadas para tomateiros sadios somente por enxertia. O levantamento revelou que, à semelhança do que ocorre no restante do país, begomovírus são predominantes nas lavouras de tomate da Ibiapaba e que as plantas invasoras ali encontradas podem ser fontes de infecção viral para a cultura.
\end{abstract}

Palavras-chave adicionais: Lycopersicon esculentum, vírus de tomateiro, hospedeiros alternativos, transmissão de vírus.

\begin{abstract}
Predominance of begomovirus on tomato in Chapada da Ibiapaba, Ceará, and its natural detection on weeds plants

Tomato, Lycopersicon esculentum Mill., is an important vegetable in Brazil but presents serious problems concerning pathogen infections, mainly viruses. The viruses infecting tomato in Brazil belong to the genera Begomovirus, the most common and Potyvirus, Cucumovirus, Tospovirus and Tobamovirus. In the state of Ceará, although there are reports about the incidence of different viruses in plantations of tomato in the Chapada da Ibiapaba, the main producer of the state, there is a lack of information on the current situation of begomovirus in that region. The present work aimed to investigate the occurrence of begomovirus in tomato plantations of Ibiapaba region; to verify the presence of infected weeds; and to evaluate artificial transmission of begovomovirus from tomatoes or weeds to tomatoes. Serological tests and PCR revealed the presence of begomovirus in 'Alambra', 'Densus', 'Monalisa', 'Santa Clara', Sheila', 'Sofia', 'Raisa-N' and 'TY- Fanny' cultivars and hybrids most cultivated in the sampled counties. Besides begomovirus, Cucumber mosaic virus (CMV) and Potato virus Y (PVY) were also detected in the region. The weeds species Amaranthus spinosus, A. viridis, Ageratum conyzoides and Bidens pilosa were found to be hosts of begomovirus hosts. The virus was transmitted by grafting and mechanical transmission among tomato plants. Begomovirus transmission from infected weeds to tomato plants occurred by grafting. The survey revealed that begomovirus was predominant in the tomato plantations in the Ibiapaba region and that the weeds can be sources of begomovirus to tomato plantations.
\end{abstract}

Additional keywords: Lycopersicon esculentum , tomato viruses, survey, hosts for begomovirus, virus transmission.

O tomateiro, Lycopersicon esculentum Mill., é uma hortaliça de grande aceitação em diferentes mercados consumidores. Os vírus mais comuns nessa cultura pertencem aos gêneros Begomovirus, Potyvirus, Cucumovirus,

Parte da Dissertação de Mestrado da primeira autora. Universidade Federal do Ceará. Fortaleza CE. 2005.
Tospovirus e Tobamovirus (Resende \& Cupertino, 1996; Faria et al., 2000). Os begomovírus têm se destacado em tomateiro nas principais regiões produtoras do Centro-Oeste, Sudeste e Nordeste do Brasil desde a década de 90, quando causaram sérios prejuízos, que variaram de 40 a $100 \%$, com subseqüente comprometimento da indústria de processamento de tomate (Faria et al., 2000). Plantas daninhas têm sido relatadas como hospedeiras alternativas de 
begomovírus em várias regiões e, supostamente, constituem fonte potencial do vírus para o tomateiro, podendo ainda estar associadas à emergência de novas espécies de vírus desse gênero no campo (Ambrozevícius et al., 2002; Lima et al., 2002).

No estado do Ceará, a microrregião da Ibiapaba tem destaque especial no cultivo de diversas hortaliças, sendo a cultura do tomateiro uma das mais exploradas comercialmente (Lima et al., 2000). No final da década de 70 , poucos anos após o início da exploração econômica da hortaliça na região, o surgimento de vírus, como o Tobacco mosaic virus (TMV), foi observado causando sérios prejuízos na produção de tomate. Posteriormente, a suspeita da incidência de novas viroses em tomateiros foi levantada em razão do aparecimento de sintomas distintos do mosaico causado por TMV. Os problemas relacionados com fitovírus, contudo, agravaram-se a partir de 1997 com a introdução da mosca branca (Bemisia tabaci biótipo B) nas áreas produtoras (dados não publicados), de modo que elevadas populações do vetor foram registradas nos anos seguintes por Lima et al. (2000). Sintomas de mosaico acompanhado de clorose, de encrespamento, redução foliar e de subdesenvolvimento das plantas, associados à queda na produção, tornaram-se comuns nas lavouras de tomateiro. Ao término daquela década, a presença de begomovírus foi registrada nos tomatais da Ibiapaba (Lima et al., 2000). Apesar dos relatos de incidência de viroses em lavouras comerciais de tomateiros da Chapada da Ibiapaba, a escassez de informações sobre a situação atual dos begomovírus na cultura, somada à ameaça que esses vírus representam, motivaram a realização deste trabalho, o qual teve por objetivos: levantar a presença de begomovírus nos cultivares e híbridos de tomateiros explorados comercialmentenas lavouras na Ibiapaba; verificar a existência de plantas daninhas infectadas com begomovírus; investigar a transmissão artificial de begomovírus isolados de tomateiro e de plantas daninhas para o tomateiro.

\section{Coleta de amostras de tomateiros e de plantas daninhas nas lavouras}

O levantamento de begomovírus nas áreas produtoras de tomate da Ibiapaba foi realizado mediante coletas em pequenas propriedades em quatro diferentes períodos: setembro de 2003, fevereiro de 2004, setembro de 2004 e maio de 2005. Foi visitado um total de 47 lavouras de tomate localizadas nos municípios de Guaraciaba do Norte (40), Croatá (4) e Ipú (3), sendo que este último foi incluído somente nas coletas realizadas em setembro de 2004 e maio de 2005. Nessas lavouras, além de tomateiros, foram também coletadas plantas daninhas, principalmente em áreas com maior incidência de vírus e população elevada do vetor. No total, foram coletadas mais de 1.200 amostras de tomateiros, entre plantas inteiras e amostras foliares, com sintomas de mosaico de aspecto clorótico, folhas encrespadas e redução no crescimento, sugestivos de infecção por begomovírus, observado em 70 a $80 \%$ das plantas nas lavouras. Estas amostras pertenciam a 24 cultivares e híbridos: 'Santa
Clara'(98 amostras) (grupo Santa Cruz); 'TY-Infinity'(49), 'TY-Fanny'(79), 'Densus'(135), 'Possanga'(18), 'TY6692'(10), 'TY-5923'(17), 'TY-5924'(8) e 'TY-5925'(5), 'Sheila'(58), 'Alambra'(60), 'Sofia'(103), 'Primus'(9), 'Raisa-N'(7), 'Monalisa'(283), 'Carmem'(19), 'Diva'(5), 'Thomas'(19), 'Helena'(15), 'Alboran'(28), 'Neta'(14), '4392'(42) (grupo Salada); 'Ipa 6'(110) e 'SM 16'(28) (grupo Agroindustrial). Na maioria das lavouras eram plantadas de um a três cultivares ou híbridos de tomate, que foram coletadas conforme o sintoma apresentado e a dimensão da área plantada por cultivar.

Para verificar a presença de hospedeiras alternativas de begomovírus nas lavouras de tomateiro, coletou-se um total de 135 plantas daninhas apresentando ou não, sintomas sugestivos de viroses. As amostras foliares coletadas foram numeradas, conforme a área de coleta, acondicionadas em sacos plásticos e mantidas sob refrigeração, enquanto que as plantas inteiras, tanto de tomateiro como de plantas daninhas, foram transplantadas para vasos em casa de vegetação, visando posterior realização de testes específicos para identificação e transmissão viral. Todas as plantas foram semanalmente pulverizadas com inseticidas sistêmicos para o controle, principalmente, da mosca branca. Amostras das plantas daninhas coletadas foram herborizadas e conduzidas para o Setor de Sistemática Vegetal do Departamento de Biologia da Universidade Federal do Ceará (UFC) para a correta identificação das espécies.

\section{Testes sorológicos e PCR para detecção de vírus}

Nos dois primeiros períodos (setembro de 2003 e fevereiro de 2004), em algumas lavouras havia tomateiros exibindo sintomas apenas de mosaico sem deformações ou de necrose no limbo foliar com enrolamento, diferente daqueles comumente observados nas infecções por begomovírus e presente na grande maioria das plantas no campo.

A análise das amostras de tomateiros coletadas nesses períodos foi inicialmente realizada mediante o uso de testes sorológicos: dupla difusão em ágar e ELISA indireto (Almeida, 2001). Considerando os sintomas acima citados, no teste de dupla difusão, foram usados anti-soros contra TMV e Cucumber mosaic virus (CMV), empregandose meio com SDS e sem SDS, respectivamente. No ELISA empregaram-se anti-soros contra CMV, Potato virus Y (PVY), como também um anti-soro produzido na Flórida contra o begomovírus Macroptilium golden mosaic virus (MaGMVFL) (Cancino et al., 1995), vírus sorologicamente relacionado com begomovírus de tomateiro e já empregado na diagnose desses vírus com resultados confiáveis (Lima et al., 2000). Os anti-soros foram cedidos pelo Laboratório de Virologia Vegetal da UFC. A leitura da absorbância das placas foi realizada na leitora de ELISA Labsystems Multiskam MS, utilizando-se o comprimento de onda de $405 \mathrm{~nm}$.

Em razão dos testes sorológicos iniciais revelarem que o TMV não estava presente em nenhuma das amostras das 18 cultivares e híbridos coletadas em setembro de 2003 e fevereiro de 2004 e, considerando que tais cultivares e 
Predominância de begomovírus em tomateiros na região produtora...

híbridos explorados comercialmente na Ibiapaba possuem resistência a tobamovirus (Alvarenga, 2004) e a presença de TMV há muito não era reclamada na área, optou-se por não realizar novos testes sorológicos para esse vírus no material coletado nos períodos posteriores.

A análise de amostras foliares de tomateiros e de plantas daninhas, coletadas em setembro de 2004 e maio de 2005, foi realizada mediante a utilização somente da técnica PCR (Polymerase Chain Reaction). Para tanto, foi procedida a extração do DNA total das amostras foliares baseada no protocolo elaborado por Dellaporta et al. (1983). O DNA total obtido de cada amostra, foi ressuspenso em $300 \mu \mathrm{L}$ de água milli-Q, posteriormente diluído a 1:10 em água milli-Q e acondicionado a $-20{ }^{\circ} \mathrm{C}$ para posterior uso na reação da PCR. Foi empregado o par de oligonucleotídeos: 5'-CCCGTCGACATGYCTAAGMGKGAKGCCCC-3' e 5'-CCCCTGCAGAACTTCCAAGTCTGGACG-3', que amplificam fragmentos de $0,9 \mathrm{~kb}$ do DNA A, referente à capa protéica de begomovírus (Rojas et al., 1993). O programa utilizado na amplificação do genoma viral no termociclador foi o de aquecimento inicial a $94{ }^{\circ} \mathrm{C} / 3 \mathrm{~min}$ e 35 ciclos compostos de desnaturação $\left(94{ }^{\circ} \mathrm{C} / 1 \mathrm{~min}\right)$, anelamento $\left(55^{\circ} \mathrm{C} / 1,5 \mathrm{~min}\right)$ e extensão $\left(72^{\circ} \mathrm{C} / 1,5 \mathrm{~min}\right)$, seguido de extensão final a $72{ }^{\circ} \mathrm{C} / 7 \mathrm{~min}$. Após a eletroforese em gel de agarose a $1 \%$ tratado com brometo de etídeo, os fragmentos amplificados de DNA foram visualizados sob luz ultravioleta.

\section{Inoculação mecânica e enxertia}

Tomateiros e plantas daninhas, mantidos em casa-de-vegetação, que apresentaram resultados positivos para begomovírus, tanto no ELISA como na PCR, foram utilizados como fonte de vírus nos testes de transmissão por inoculação mecânica e enxertia. $\mathrm{Na}$ inoculação mecânica foram utilizadas mudas sadias de tomateiro 'Santa Clara' na fase de duas folhas verdadeiras. Para o inóculo, folhas novas e infectadas foram trituradas em presença de tampão de fosfato de potássio $0,05 \mathrm{M}, \mathrm{pH} 7,5$ acrescido de $0,1 \%$ de sulfito de sódio, na proporção 1:2 (p/v). Pedaços de gaze umedecidos com o inóculo obtido dos tomateiros ou de plantas daninhas foram friccionados na superfície adaxial das folhas de mudas de tomateiro, previamente polvilhadas com o abrasivo 'Carborundum'. Para a transmissão por enxertia, brotações ou seções de ramos novos de tomateiros e de plantas daninhas infectadas foram enxertadas por garfagem em tomateiros sadios 'Santa Clara', no estádio de quarta folha verdadeira. O número de tomateiros enxertados variou em função do número de plantas daninhas infectadas de uma mesma espécie. Os tomateiros enxertados foram dispostos em gaiolas revestidas com telas contra insetos e, para segurança do ensaio, semanalmente pulverizados com inseticidas sistêmicos contra mosca branca. Em ambos os tipos de transmissão, as plantas foram mantidas em casa de vegetação para observação do surgimento de sintomas e posterior realização da PCR para constatação de infecção viral.
Vírus detectados nos tomateiros por sorologia e,ou, PCR

Os resultados dos testes sorológicos realizados com as amostras foliares dos tomateiros 'Sofia', 'Densus', 'Monalisa', 'Alboran', 'Santa Clara', 'Alambra', 'Sheila', 'Carmem', 'TY-Fanny', 'Ipa 6', 'Neta', 'Diva', '4392' e 'TY-5923'coletados em 10 lavouras em Guaraciaba do Norte e em Croatá, em setembro de 2003, e nos cultivares e híbridos 'Densus', 'Monalisa', 'Santa Clara', 'Alambra', 'Sheila', 'Carmem', 'TY- Fanny', 'Ipa 6', '4392', 'TY-5923', 'TY-6692', 'Raisa N', 'Thomas', 'TY- Infinity' e 'Helena' coletados em nove lavouras em fevereiro de 2004 nos mesmos municípios, revelaram a presença de CMV em apenas $14 \%$ das 107 amostras de tomateiro testadas e somente na cultivar Santa Clara, que exibia o mosaico já mencionado, em uma das lavouras em Guaraciaba do Norte (set/2003). Apesar de possuir grande número de hospedeiros, o CMV não é muito freqüente na cultura do tomateiro na região e, de acordo com Resende \& Cupertino (1996), nem limitante para a cultura.

O PVY, por outro lado, foi detectado em $100 \%$ das amostras (81) coletadas dos tomateiros 'Sofia' e 'Densus', ambos cultivados em uma lavoura do município de Guaraciaba do Norte, e dos tomateiros 'Densus' e 'TYFanny’ em uma lavoura situada em Croatá. A constatação da presença desse vírus ocorreu somente na primeira inspeção, em setembro de 2003. As folhas dos tomateiros infectados apresentavam, de uma maneira geral, áreas necróticas entre as nervuras e um leve enrolamento, sintomas incomuns nos tomatais da região. Apesar da infecção, o porte das plantas e a produção das mesmas, aparentemente, não foram muito afetados, sugerindo infecção tardia. Este é o primeiro relato do PVY na região da Ibiapaba. Plantas com sintomas típicos da infecção por este potyvírus não foram encontradas nas inspeções posteriores. Pulverizações intensas com inseticidas para controle de vetores é uma prática rotineira na maioria das lavouras da região o que pode, em parte, explicar a ausência do CMV e do PVY, vírus transmitidos por afídeos, na maior parte das propriedades visitadas.

Através do ELISA indireto realizado com o antisoro produzido para o MaGMV-FL, foi possível detectar begomovírus em amostras dos tomateiros 'Raisa-N', 'Alambra', 'Monalisa', 'Densus' e 'Santa Clara', coletadas nas 19 lavouras de Guaraciaba do Norte, tanto no período seco (set/2003), quando a população do vetor estava mais elevada, como no chuvoso (fev/2004), apesar de ser mais reduzida a presença do inseto. As lavouras estavam visivelmente mais afetadas pelo begomovírus no período seco que na época chuvosa. Com exceção do 'Densus', os demais tomateiros infectados que compuseram as amostras testadas, não possuem a resistência genética a begomovírus. O 'Densus', híbrido com resistência denominada de TY, em razão de sua resistência ao Tomato yellow leaf curl virus, TYLCV, não relatado no Brasil, apresentava, contudo, sintomas brandos. A infecção por begomovirus neste tipo de tomateiro resistente pode vir a ocorrer, dependendo da população de mosca branca presente e do estágio em que a planta é 
infectada, porém sua produtividade é praticamente mantida (Geminivírus, 2004). Em geral, os sintomas apresentados pelos tomateiros infectados foram os de mosaico clorótico e encrespamento, já citados anteriormente, comumente associados à infecção por begomovírus pelos produtores da região. Nos demais tomateiros 'Sheila', 'Carmem', 'Helena', 'Ipa 6', 'Thomas', '4392', 'TY-5923', 'TY6692', 'TY- Fanny', 'TY- Infinity', coletados nas mesmas ocasiões e lavouras, o ELISA não constatou infecção por begomovírus. Desses 10 híbridos não infectados, os quatro últimos apresentam a resistência TY e seis são suscetíveis. Estes, na fase inicial de seu crescimento, estiveram sob constantes pulverizações de inseticidas específicos para a mosca branca vetora, o que pode ter contribuído para que a infecção não se estabelecesse até o momento da visita. A freqüente aplicação desses defensivos tem sido associada às áreas de menor ocorrência da virose. O plantio escalonado com diferentes cultivares ou híbridos numa mesma lavoura é prática adotada pelos produtores da região.

De acordo com os resultados obtidos pela técnica da PCR, dentre as cultivares e híbridos coletados em 12 lavouras em setembro de 2004, ('Sofia', 'Sheila', 'Possanga', 'Ipa 6', 'Ty-Infinity', 'Densus', '4392', 'Ty-6692' e 'SM 16') e em 12 lavouras em maio de 2005 ('Sheila', 'Possanga', 'Ipa 6', 'TY-Infinity', 'Densus', 'TY-Fanny', 'Alambra' e 'Monalisa'), apresentaram infecção por begomovírus mais de $60 \%$ de amostras dos tomateiros 'Sheila', 'Densus', 'TY-Fanny', 'Alambra' e 'Monalisa' oriundos das lavouras de Guaraciaba do Norte e de Ipu visitadas em ambos os períodos. Constatou-se, também, que esses cinco cultivares eram os mais cultivados na maioria das lavouras visitadas e, por esta razão, foram mais freqüentemente incluídos nos testes. Nos casos em que as moscas brancas virulíferas chegaram mais cedo nessas lavouras (período seco), o prejuízo pela infecção viral ocorreu em razão do reduzido porte das plantas e sintomas foliares bem acentuados. Em Croatá, nas 04 lavouras menores visitadas, begomovírus não foi detectado nas plantas coletadas. As cultivares encontravam-se na fase inicial de desenvolvimento sob constantes pulverizações contra a mosca branca.

Em geral, observou-se que a diversidade do material genético dos tomateiros (24 cultivares e híbridos) cultivados nas lavouras da Chapada da Ibiapaba, juntamente com a oscilação periódica da população de insetos vetores em função das chuvas, parece estar relacionado à variação no percentual de plantas com begomovírus.

\section{Plantas daninhas infectadas e transmissão viral para tomateiro}

As plantas daninhas coletadas nas lavouras de tomateiro da Ibiapaba, nas quatro visitas, eram de 18 espécies vegetais em sete famílias botânicas (Tabela 1). Detectou-se, tanto por ELISA como por PCR, a presença de begomovírus em Amaranthus spinosus L. (13/20), A. viridis L. (1/5), Ageratum conyzoides L. (6/37) e Bidens pilosa L. (2/8) (Tabela 1). Sintomas sugestivos de infecção viral nas plantas daninhas não foram observados. Ressalta-se que o número de plantas coletadas e testadas para cada espécie variou em função de sua população nas áreas com tomateiros visivelmente afetados por begomovírus.

Testes realizados em anos anteriores (2001 e 2002) por Santos et al. (2003) com amostras coletadas no município de Tianguá $\mathrm{CE}$, localizado nessa mesma região serrana, revelaram a infecção de begomovírus em Amaranthus deflexus L., $A$. spinosus, Acanthospermum hispidum DC., B. pilosa, Borreria capitata DC. e Euphorbia heterophylla L. Contudo, sintomas visíveis de infecção viral não foram observados. A coleta das plantas daninhas foi efetuada em função da sua presença comum em áreas com muitos tomateiros infectados e alta população de mosca branca. Relatos de outras espécies de plantas daninhas associadas a begomovírus já foram obtidas por Lima et al. (2002) e Assunção et al. (2004).

O percentual de transmissão de begomovírus de tomateiro infectado para mudas de tomateiro sadias foi reduzido, tanto nas inoculações mecânicas (5\%) como nas enxertias (30 \%). Informações semelhantes já foram relatadas por Rocha (1999). A utilização, em alguns casos, de folhas ou seções de ramos novos, de plantas em fase de frutificação, quando a concentração viral normalmente se reduz, pode ter contribuído para o baixo percentual de infecção nos dois tipos de inoculação.

Não houve transmissão mecânica de begomovírus entre plantas daninhas e tomateiro. Na transmissão por enxertia foram empregadas seções de caule de $A$. spinosus, $A$. conyzoides e $A$. viridis. Ainda que provenientes de plantas de famílias botânicas distintas, os enxertos das espécies daninhas em tomateiros mostraram-se viáveis, embora a transmissão tenha ocorrido para somente uma planta de tomateiro em cada caso: $A$. spinosus $(1 / 44=2,27 \%)$, A. conyzoides $(1 / 26=3,84 \%)$ e $A$. viridis $(1 / 11=9,09 \%)$. Estes resultados demonstram que a transmissão de begomovírus de plantas daninhas para tomateiros pode ocorrer. Vale ressaltar que não foi investigada a concentração viral nas folhas destacadas por ocasião dessas enxertias. Para o presente trabalho, é possível supor-se que melhores resultados teriam sido obtidos com o emprego de seções de plantas daninhas infectadas em estádios iniciais de desenvolvimento. A transmissão no sentido inverso, ou seja, de tomateiros infectados para plantas daninhas, por meio de inoculação artificial e empregando-se o inseto vetor, deve ser investigada.

Das quatro espécies de plantas daninhas infectadas encontradas na região da Ibiapaba, A. conyzoides e A. viridis não haviam ainda sido citadas como hospedeiras de vírus do gênero Begomovirus na região Nordeste. Contudo, as quatro espécies referidas são encontradas com freqüência nas lavouras de tomateiro e nelas, comumente, observou-se a presença da mosca branca em suas folhas, demonstrando a movimentação do inseto entre as espécies de plantas daninhas e o tomateiro. Em condições naturais, é possível que haja a transmissão de vírus entre hospedeiras alternativas e plantas cultivadas, visto que a atividade dos insetos vetores em campo, principalmente sob altas populações, é mais intensa podendo chegar mais cedo nos novos plantios (Costa, 1976). 
Predominância de begomovírus em tomateiros na região produtora...

TABELA 1 - Plantas daninhas coletadas e, ou, infectadas por begomovírus em cultivos de tomateiro (Lycopersicon esculentum) na região da Ibiapaba, de setembro de 2003 a maio de 2005

\begin{tabular}{|c|c|c|c|c|}
\hline Família & Espécie & Nome vulgar & $\begin{array}{c}\text { Total de plantas } \\
\text { coletadas }\end{array}$ & $\begin{array}{c}\text { Plantas infectadas } \\
\text { Testadas* } \\
\end{array}$ \\
\hline \multirow[t]{6}{*}{ Amaranthaceae } & Alternanthera ficoidea & Ervanço & 2 & $0 / 2$ \\
\hline & Alternanthera sp. & & 4 & $0 / 4$ \\
\hline & Amaranthus spinosus & Bredo-branco & 31 & $13 / 20$ \\
\hline & & Bredo de espinho & & \\
\hline & & Caruru de espinho & & \\
\hline & Amaranthus viridis & $\begin{array}{l}\text { Bredo,Caruru, } \\
\text { Caruru de mancha }\end{array}$ & 5 & $1 / 5$ \\
\hline \multirow[t]{11}{*}{ Asteraceae } & Ageratum conyzoides & Catinga de bode & 45 & $6 / 37$ \\
\hline & & Erva-de-são-joão & & \\
\hline & & Mentrasto & & \\
\hline & Acanthospermum hispidum & Carrapicho de carneiro & 6 & $0 / 4$ \\
\hline & & Chifre de veado & & \\
\hline & & Espinho de carneiro & & \\
\hline & Bidens pilosa & Picão, Picão preto & 8 & $2 / 8$ \\
\hline & & Fura-capa & & \\
\hline & Blainvillea rhomboidea & Camaratuba preta & 2 & $0 / 2$ \\
\hline & Centratherum punctatum & Perpétua roxa & 3 & $0 / 3$ \\
\hline & Conocliniopsis prasiifolia & Balaio de veio & 2 & $0 / 2$ \\
\hline Commelinaceae & Commelina sp. & - & 5 & $0 / 5$ \\
\hline Convolvulacea & Merremia aegyptia & $\begin{array}{l}\text { Batatão roxo, } \\
\text { Corda de viola } \\
\text { Jetirana }\end{array}$ & 3 & $0 / 3$ \\
\hline Fabaceae & Senna uniflora & Mata pasto cabeludo & 2 & $0 / 2$ \\
\hline \multirow[t]{3}{*}{ Portulaceae } & Portulaca oleracea & Beldroega & 2 & $0 / 2$ \\
\hline & & Bredo de porco & & \\
\hline & & Ora-pro-nobis & & \\
\hline \multirow[t]{2}{*}{ Rubiaceae } & Borreria sp. & - & 6 & $0 / 5$ \\
\hline & Richardia grandiflora & Fato de piaba & 3 & $0 / 3$ \\
\hline \multirow[t]{4}{*}{ Solan aceae } & Solanu m americanum & Erva de bicho & 3 & $0 / 2$ \\
\hline & & Erva moura & & \\
\hline & & Maria pretinha & & \\
\hline & Physalis sp. & - & 3 & $0 / 3$ \\
\hline Total & & & 135 & $22 / 112$ \\
\hline
\end{tabular}

*Algumas plantas morreram durante o período de realização do teste e por essa razão somente 112 plantas foram testadas por ELISA e, ou, PCR.

Atualmente, a tentativa de redução da incidência de begomovírus nas lavouras da Ibiapaba, por parte dos produtores da região, concentra-se na utilização de material genético resistente ao TYLCV e no emprego intensivo de inseticidas contra a mosca-branca. $\mathrm{O}$ controle desse inseto na Chapada de Ibiapaba é dificultado, ora em virtude da vegetação espontânea que inclui espécies hospedeiras do aleirodídeo, ora pelo abandono pelos produtores de lavouras de tomate fortemente acometidas pela praga. A retirada de plantas daninhas da área não é ainda uma prática adotada na região.

Os resultados deste trabalho apresentam relevante contribuição para o conhecimento das viroses que incidem atualmente na cultura do tomateiro na Chapada da Ibiapaba, revelando que begomovírus, presentes em pelo menos 40 das 47 lavouras visitadas, são os vírus predominantes e que afetam a produção da cultura naquela região. É possível ainda supor que haja mais de uma espécie de begomovírus ocorrendo nas áreas produtoras, tendo em vista a diversidade do material genético de tomateiro, a existência de diferentes espécies de plantas daninhas hospedeiras alternativas desses vírus e a presença contínua da mosca branca nas lavouras.

\section{AGRADECIMENTOS}

O primeiro autor agradece à CAPES pela concessão de bolsa de estudos. Projeto financiado pela FUNCAP/ UFC. Processo 385/01. Agradecemos às colegas Maria do Carmo L. Silva e Cláudia Araújo Marco pela colaboração nas coletas realizadas na região da Ibiapaba $\mathrm{CE}$ e a Vanúzia B. Oliveira, Aline Kelly Q. Nascimento e Maria de Fátima B. Gonçalves pela contribuição na realização dos testes sorológicos e PCR para a detecção viral. 


\section{REFERÊNCIAS BIBLIOGRÁFICAS}

ALMEIDA, A.M.R. Detecção e quantificação de vírus pelo teste de Elisa. In: Almeida, A.M.R \& Lima, J.A.A. (Eds.) Princípios e técnicas de diagnose aplicados em fitovirologia. Brasília DF. Sociedade Brasileira de Fitopatologia. 2001. pp. 63-94.

ALVARENGA, M.A.R. Cultivares. In: Alvarenga, M.A.R. (Ed.) Tomate: produção em campo, em casa-de-vegetação e em hidroponia. Lavras MG. Editora UFLA. 2004. pp. 37-59.

AMBROZEVICIUS, L.P., CALEGARIO, R.F., FONTES, E.P.B., CARVALHO, M.G. \& ZERBINI, F.M. Genetic diversity of begomovirus infecting tomato and associated weeds in Southeastern Brazil. Fitopatologia Brasileira 27:372-377. 2002.

ASSUNÇÃO, I.P, BARROS, M.C.S., LOPES, A.C.P.A., LIMA, G.S.A., AMORIM, E.P. R., SILVA, D.M.W. \& RAMALHO-NETO, E. Detecção de begomovirus em plantas invasoras no estado de Alagoas. Fitopatologia Brasileira 29(Supl.):162. 2004. (Resumo)

COSTA, A. S. Whitefly-transmitted plant diseases. Annual Review Phytopathology 14:429-449. 1976.

CANCINO, M., HIEBERT, E., PURCIFULL, D., POLSTON, J.E. \& MORALES, F.J. Monoclonal antibody with broad specificity to white-fly transmitted geminivirus. Phytopathology 85:484-501. 1995.

DELLAPORTA, S.L., WOOD, J. \& HICKS, J.B. A plant DNA minipreparation: version II. Plant Molecular Biology Reporter 1:19-21. 1983.

FARIA, J.C., BEZERRA, I.C., ZERBINI, F.M., RIBEIRO, S.G. \& LIMA, M.F. Situação atual das geminiviroses no Brasil.
Fitopatologia Brasileira 25:125-137. 2000.

GEMINIVÍRUS - Revista Cultivar. Disponível em: $<$ http:www. clicknoticia.com.br/clipp.asp?clip=497>. Acesso em: 20 ago. 2004.

LIMA, G.S.A., ASSUNÇÃO, I.P., MELO-FILHO, L.R., MONTEIRO, L.C.C., VIANA, T.H.P. \& FREITAS, N.S. Novas espécies de Begomovirus associadas a plantas invasoras no estado de Pernambuco. Fitopatologia Brasileira 27(Supl.):207. 2002. (Resumo)

LIMA, J.A.A., GONÇALVES, M.F.B., OLIVEIRA, V.B., TORRES-FILHO, J. \& MIRANDA, A.C.M. Serological and PCR detection of a Begomovirus infecting tomato fields in Ibiapaba Mountain, Ceará. Fitopatologia Brasileira 25:104-108. 2000.

RESENDE, R.O. \& CUPERTINO, F.P. Doenças causadas por vírus em tomateiro. Informe Agropecuário 184:19-27. 1996.

ROCHA, H.G.C. Caracterização de três isolados de geminivírus transmitidos por mosca branca (Bemisia argentifolii Bellows e Perring) infectando tomate (Lycopersicon esculentum Mill.) na região do Submédio do São Francisco. Dissertação de Mestrado. Brasília DF. Universidade de Brasília. 1999.

ROJAS, M.R., GILBERTSON, R.L., RUSSEL, D.R. \& MAXWELL, D.P. Use of degenerate primers in the polymerase chain reaction to detect whitefly-transmitted geminivirus. Plant Disease 77:340-347. 1993.

SANTOS, C.D.G., GONÇALVES, M.F.B. \& OLIVEIRA, O.R. Detecção, por ELISA, de Begomovirus em plantas daninhas presentes em áreas produtoras de tomateiro no estado do Ceará. Fitopatologia Brasileira 28(Supl.):252. 2003. (Resumo)

Recebido 17 Maio 2006 - Aceito 8 Junho 2007 - FB 6056 